\title{
Index
}

adoption

as a complex social process 50, 80, 99

and envaluation 77

of European materials by colonized peoples 81,85

heterarchical vs. hierarchical models of influence 96

influence of aggrandizing elites 91

influencers and 94

kin support for 100

non-linear process of 144

in organizational studies and marketing 79

personal networks and 93

predictive models of 90

through re-classification or translation 85

shaped by social networks 80

social factors in 90

thin explanations for in archaeology 87

aggrandizing elites 37

and the emergence of inequality 91

and the origins of agriculture 42

and prestige goods 92

vs. influencers 95

Amish, role of tradition among the 155

Annaliste school 54

anti-innovation 1

in nineteenth-century Norway 154

apprenticeship

conservatism of, critiqued 114

within guilds 114

and learning by doing 112

linked to specialized

technologies 113

and social relationships/kinship 114 behavioral archaeology, formation processes 56

behavioural ecology demography 178

origins of agriculture 42

boundary objects 116

in Ancestral Pueblo ceramic traditions 116

Dreaming tracks or "songlines" as 128

at frontiers 123

bricolage approach 3, 186

change

by external pressure 28, 43, 141

as normative 86

shaped by tradition 155

as socially regressive 150

temporality of 8

vs. non-change 71

vs. progress 4

Childe, V. Gordon archaeological cultures 54

and archaeological innovation studies 190

Eurasian prehistory 28

"Neolithic Revolution" model 12, 28

clustering of innovations

in cores vs. peripheries or margins 66,121

disregard of hinterlands, critiqued 122

regional innovation systems 119

as a result of guild-sponsored apprenticeships 115

and social geographies 128

spatial and temporal 119

unnecessary in some industries 122

cognitive revolution 177 
colonialist narratives

of adoption 93

about agriculture 39

and archaeological model-building

142,188

of collapse and displacement 86

of contact as rupture with the

past 85

countered by re-framing as persistence narratives 153

non-European societies as unchanging 10

and parsimonious models 141

and racist depictions of Indigenous

Australians 10

re-framed by Indigenous

practices 84

of resistance to innovation 11

of technological dominance 13

communal innovation 179

communication

dissemination and mass

media 127

frontiers in networks of 123

gendered patterns of 98

and geographic models 118

and kinship 99

and oral traditions 127

role of early adopters 93

through social networks and 80

communities of practice 112, 115

archaeological research into 115

and invention 70

and knowledge recombination 76

within regional innovation

systems 119

and resistance to innovation 157

conservatism

in American politics 129

in ceramic traditions 110

complex temporality of 155

complexity and heterogeneity 142

enfolding innovation 156-8

negative perceptions of 129

in Palaeoindian lithic technology

in Brazil 140

as process 154

in Roman Cornwall 131

as settlement continuity 146

social vs. technological 129

as status quo in small-scale societies, critiqued 141

in the tech sector 150

constructivism see SCOT contextual archaeology and the origins of metallurgy 67

continuity

as normative in culture-history models 54

of practices 138

product of teaching and learning activities 139

as reinvention 115

settlement 146

and social cohesion 139

cooking

as a domain of gendered power negotiation 139

part of ethnic identity 134

creative destruction 147, 185

as a rationale for resisting innovation 184-5

in the tech sector 147

as a threat to individuals and social classes 148

creativity

as distinct from innovativeness 160

equivalent to social dynamism 14

and invention 69

in psychology 166

re-combination and re-mixing 76

cross-craft knowledge 58, 113

in agriculture 57

and invention 67

and skeuomorphism 74

culture-history models 27,54

conservatism and

homogeneity in 141

de-evolution 10

Lapita, critiqued 107

demic diffusion 44, 125

demographic models

behavioral ecology 178, 179

critiqued 178

and propinquity 119

demographic pressure

within heterogeneous networks 180

lack of leading to stasis 140

descent with modification 43

diffusion

through communication networks 118,124

defintion of 118

and hyper-diffusionism 34

neighborhood effect 119

through personal networks 103

vs. migration 124 
disruption 147

see also creative destruction

Djulirri 83, 84

Do-Need framework 87, 88 critiqued 90

dual inheritance theory 43 and mechanisms for knowledge transfer 116

early adopters influence in social networks 49, 93 as influencers 94 role in communicating innovations 103

efficiency 89

envaluation 77

of European materials by colonized people 85

environmental determinism and archaeology 145 origins of agriculture 41 push-pull factors 145

Eurocentrism in adoption narratives 93 and conceptions of change 141 in evolutionary models 41 and ontology 39 and the origins of agriculture 39

European prehistory lithic implements and metallurgy in 68,74 metallurgy and globalization 63 metalworking technologies in 113 narratives of metal adoption in 64, $68,113,140$

ornamentation and the origin of metallurgy 63, 65

social context of metalworking in 66 evolution culture theory see evolutionary archaeology

evolutionary archaeology 33

assumption of normative change 117 colonialism 188

critiqued 43, 188

cultural virus theory 116

evolution culture theory 41

explanations for stasis 140

functionalism 30

heteronormativity of 47

invention in 69

memetic transfer, critique of 117

models of knowledge transmission 116

niche construction theory 87

selectionist approaches 42 and specific evolutionary principles 43

in studies of innovation 42

failure to innovate 143 complex decisions behind 147

feminist approaches 20

anthropological 188

to evolutionary models of social change 46,47

post-humanism 25

in technology studies 18,25

flint daggers 68 and aggrandizing elites 92

as boundary objects 116

as skeuomorphs 74

functionalism

and archaeology 86, 145

in behavioral archaeology 46

Do-Need framework 87

as a rationale for innovation failure, critiqued 144

Great Man narratives 18, 19

see also solitary genius

heterogeneous networks

in agriculture 39

and communities of practice 115

demographic pressure within 180

homoestasis and flux 180

as mother of innovation 124

post-humanist conceptions of 180

Homo economicus 43, 90

Homo neanderthalensis see

Neanderthals

human-object networks 25, 39, 76, 180

cut by innovations 149

hybridity 86

and creativity 169

in the post-colonial Pacific 153

Romano-British 131

imitation

and authenticity 73

as creative practice 75,113

and invention 72,75

in the learning process 113

imprinting 53

Indigenous Australia

art traditions in 83, 181

colonial violence in 81

landscape management in 40

lithic technology in 81

subsistence practices in 9, 40 
Industrial Revolution 2 consumer goods manufacturing 18 and Luddism 15, 151

inequality 91 prestige goods 92

influencers 94 vs. aggrandizing elites 95

innovativeness colonialist narratives of 14 emergent in heterogeneous networks 182 masculine 19 as a response to colonialism 83 socio-linguistic models 19 integration/innovation/intrusion see "Triple I" model

invention 62, 65, 69 accidental vs. experimentation 63 assumed rarity of 36 and imitation/emulation 75 and inventors 70 non-linear 70 Marxist approaches to 28 as a social process 187 temporality of 61 vs. innovation 1,69

\section{Kastom 153}

as resistance 153

knowledge transfer and boundary objects 116 ceramic technology 110 cultural cumulation and ratcheting 117 evolutionary models 116 vertical vs. horizontal 111

knowledge transmission see teaching and learning activities

ladder of inference 32

laggards stereotypes about 138

Lapita

of archaeological research history 104

and Austronesian language dispersal 108

ceramic traditions 107-8, 110

decline, critiqued 107

kinship and cosmology 109

mobility and communication networks 109

regionalization 107, 108

spread in the Pacific 105 living fossils non-Europeans seen as 10, 27

Luddism 15 knowledgeable leaders 157 as protective resistance 151

maladaption 10, 183

marginality and ethnic solidarity 134 and invention 66

meme theory 116

migration and ancient genetics 125

Lapita 105 optimization models of 145 into Sahul 145

and the spread of innovations 108

vs. diffusion 124

models of innovation anthropological 16 archaeological 33, 48 in behavioral archaeology 46 evolutionary and Darwinian 40 functionalist 87 geographical 16, 54, 118, 143 historical 54 in non-human animals 47 political economy frameworks 93 sociological 16, 138

unilinear vs. complex 92 UTAUT 90

multi-scalar approaches 190 to adoption 80 in archaeological interpretation 55 communication patterns 103 to the dispersal of post-Lapita practices 109 to invention 71 to studies of innovation 56 temporality 127

nationalism

alliance to archaeology 126, 186

network models 102, 125

as fluid and opposed to static categories 126

non-innovation

in ceramic technology in the American southwest 146

unmappable 143

variety of narratives of 145

novelty, association with creativity 163 , 166,167 
open innovation 179

optimization models 178

of migration 145

of the origins of agriculture 42

origins of agriculture

and aggrandizing elites 42

archaeological explanations for 34

as a complex social practice 44

First Nations land

management 40

methods for studying 35, 37

as a mosaic 39

multiple numerous and protracted

domestication events 38

and niche construction theory 88

in northwest Europe 45

parsimonious models 35

popular narratives of 35

practice-centered approach 58

and social changes 34

southwest Asian model 37

spectrum of domesticated traits 40

parsimonious models 141

critiqued 39

of early metallurgy 64

of the origins of agriculture 35

path dependency 53

and clustering of innovations 119

and patterns of innovation resistance over time 142

peripheries

fluidity of boundaries of 126

as frontiers 123

as sites of innovation 67,122

persistence

of colonized peoples, cultures, and traditions 86, 153

Cornish identity during the Roman occupation 137

personhood 26

relational models of 29,44

post-humanism

and cyborgs 180

feminist approaches 25, 188

hominin evolution 26

power difference

invisibility in archaeological models 186

in patterns of influence and communication 97

in world-systems and globalization models 120

presentism 187 in archaeological invention narratives 62

in spatial relations of power 120

product innovation vs. process innovation 18, 94, 163

feminist critique 20

progress vs. change 4,150

see also technological progress

propinquity in communication networks 119

push-pull factors

niche construction theory 88

origins of agriculture 41

racism and social evolution 41

regional innovation systems see clustering of innovations

regression, myth of in Tasmania 10

rejection of innovations

reasons for 145

resistance

as an anti-colonial strategy 152

categories of 143

by colonized people 83,152

as creative practice 190

group predisposition to, critiqued 142

as an innovative process 154

to maintain network integrity 149

to metal technology in European prehistory 71,140

movements, social organization of 157

negative perceptions of 1

as an opposition to norms 151

racist narratives of 11

and the role of influential individuals 157

to social change incurred by innovation 149

by submerged networks 157

among twentieth-century

farmers 138

vs. disinterest 141

revolution, technological 28

Rogers, Everett

Diffusion of Innovations 17, 79,118

Roman Britain 130

Roman Cornwall

architecture 132

continuity of settlement and

subsistence 131, 135

cooking traditions 134 
curation and heirlooms 133

heterarchy 137

pottery traditions 134

Roman materials 131

Rounds 131

social structure and inheritance 132

Sahul, peopling of 145

Schumpeter, Joseph

foundational models of capitalist innovation 16

golden age of capitalism 15

invention vs. innovation 69

principle of creative destruction 147, 185

Schumpeter's gale see creative destruction

SCOT 50, 101

frequency of innovation failure and resistence 143

stabilization and closure 53, 144

situated learning 112, 118

skeuomorphism 72

and cross-crafting 74

and envaluation 76

and stimulus diffusion 124

social construction of technology see SCOT

social evolution

compared to culture history 28

influence on archaeological thought 40

nineteenth-century frameworks of 21

technological progress 21

unilinear models 22

solitary genius

critiqued 4, 71, 167, 187

specialization

aggrandizing elites 92

economics vs. cosmology 113

in metallurgy 63,75

stimulus diffusion 124

submerged networks 97

and childlore 98

and gender 98

and phatic labor 97

taphonomy and the fragmentation of the archaeological record 33, 55, 139

teaching and learning activities anthropological approaches 112 enculturation and embodied knowledge 112 evidence in technological continuity 139

and Lapita and post-Lapita pottery manufacture 110

among non-humans 111

patterns that foster innovation 110

secret/sacred knowledge 111, 113

structured by kin relations 113, 114

technological change

archaeological preoccupation with 33

behavioural archaeology 46

and colonialism 81

colonialist narratives of 86

Do-Need framework 88

Eurocentric male models of 5

evolutionary development vs. human agency 24

as an evolutionary process 40

and human society 21

interwoven with social change 149

over-simplified unilinear narratives 123

principle of symmetry 25

as a product of entanglement 180

as progress, critiqued 150

role of efficiency 89

and sophistication of social

structure 21, 41

technological determinism 88

and archaeology 186

technological progress

colonialist narratives 13

equivalent to moral superiority

13,142

evolutionary models 22

technology

as a concept 24

and human society 21

non-linear development of 24

technology studies

anthropological 77

in archaeological research 27, 29

constructivism 50

development of 22

and knowledge vs. know-how 112

tech-utopianism 16, 184

decline of 185

temporality

archaeological chronologies 27, 33

diffusion and migration 126

and the historical trajectories of innovations 53

of innovation adoption 49

of invention 61 
trade unions

enmity to innovation 150

tradition 153

as an active process 153

among the Amish 155

colonialism and the maintenance of 84

as a creative act 157

Indigenous Australian

maintenance of 82

key to Native American

resilience 153 as mediation between past and present 153, 156 opposed to progress, critiqued 155

Trethurgy Round 133

ceramic assemblage 134

curated materials 133

“Triple I" model 108 and migration 125

world-systems theory 120

archaeological approaches 120 